\title{
INTER-RELATIONSHIP BETWEEN THE HOUSING MARKET AND HOUSING FINANCE SYSTEM: EVIDENCE FROM MALAYSIA
}

\author{
Rosli SAID $^{a, *}$, Alaistair ADAIR ${ }^{b}$, Stanley McGREAL ${ }^{b}$, Rohayu MAJID ${ }^{c}$ \\ ${ }^{a}$ Department of Estate Management, Faculty of the Built Environment, University of Malaya, 50603 \\ Kuala Lumpur, Malaysia \\ ${ }^{b}$ School of the Built Environment, University of Ulster, Jordanstown campus, Shore Road, Newtownab- \\ bey, Co. Antrim, BT37 0QB, United Kingdom \\ ${ }^{c}$ Department of Estate Management, Faculty of Architecture, Planning \& Surveying, University of Tech- \\ nology Mara, 40450 Shah Alam, Selangor, Malaysia
}

Received 5 September 2012; accepted 22 March 2013

\begin{abstract}
The Malaysian housing market and associated housing finance system have expanded significantly as a result of rapid urbanisation since the late 1980s. The key aspect of this paper is to analyse the inter-relationship between the housing market and housing finance system in Malaysia. The paper employs Vector Autoregressive approach and Granger Causality test to empirically investigate this inter-relationship. In Malaysia, no housing studies has actually looked into or used this approach to identify the inter-relationship between these two elements. The key findings show that there is a strong inter-relationship between the housing market and housing finance system. The direction of causality shows that there is a bi-directional relationship between the housing market and housing finance system. These inter-relationships provide evidence that sound performance of the sub-markets within the housing finance system is a determinant prerequisite of the robustness of the housing finance system, if a healthy performance of the housing market is to be achieved.
\end{abstract}

KEYWORDS: Housing market; Housing finance; Mortgage-backed; Vector autoregressive; Causality

REFERENCE to this paper should be made as follows: Said, R.; Adair, A.; McGreal, S.; Majid, R. 2014. Inter-relationship between the housing market and housing finance system: evidence from Malaysia, International Journal of Strategic Property Management 18(2): 138-150.

\section{INTRODUCTION}

Housing often exemplifies the largest single investment item of individuals. This is normal especially as family incomes rise and housing is viewed as a key to a safe future rather than a basic consumption. This is true in any housing market. The housing market behaves the same as other asset markets. Under-valued housing detracts from the efficient allocation of scarce resources whereas over-valued contributes to inflation and oppresses economic competitiveness in the long run. The efficiency of a country's economy may be part dependent on the efficiency of housing market and the housing finance system. Within the housing market modelling literature, the housing market

\footnotetext{
* Corresponding author. E-mail: rosli_alambina@um.edu.my
}

is a subset of the macroeconomics and investment theory (Caruthers 1989). There has, however, been much less attention given to exogenous changes in housing market in relation to the housing finance system.

There are many good examples of effective housing finance models worldwide. Lea (1994), for example, concluded that the United Kingdom and the United States had the two most efficient housing finance systems, on the basis of a quantitative and qualitative analysis of mortgage credit provision. Nonetheless, the imperfect operation of housing markets may differ substantially from one country to another (Collyns, Senhadji 2002) and influence the housing finance systems. Perhaps the most basic principle of housing economics is that the performance of the housing market is influenced by the robustness of the housing finance 
system, or vice versa. Robustness of the housing finance system may refer to the ability of the system to sustain during economic crisis. The sustainability of housing finance system should create a healthy performance of the housing market since they are inter-related. In addition, short- or longterm measures introduced by government to the submarkets within the housing finance system (primary mortgage market, secondary mortgage market and capital market) especially during economic crisis should be able to create a sound performance of the overall system.

In Malaysia, the present operation of the market may be far from efficient (Agus 1997; Warnock, Warnock 2008). The transaction of houses is complex where the value of a house is determined before the actual unit is completed. Although most literature suggests that the value of a house is determined by the interaction of demand and supply, prospective homebuyers are usually compelled to depend on surrogates such as pamphlets and models and pay significant amount of money long before they see the actual units completed. In addition, when a purchaser buys a house, that purchase normally depends on a financial institution from which it can borrow a substantial amount of the needed funds. Most households will not be able to raise money from other sources, except for those which contribute to the Employee Provident Fund (EPF) to support the down payment of the purchase price.

Housing finance has been defined as the system of money and credit which enables all types of housing to be built, improved, bought, rented, maintained and repaired (Garnet et al. 1991). The aim of the system is to provide the funds which homebuyers need to purchase homes. This involves a broad range of institutional arrangements, ranging from saving schemes, to institutions specializing in mortgage finance, to the issuance, sale and trading of mortgage-backed securities (MBS). In Malaysia, the system extends support in two ways - facilitating property development for the developers and home-ownership for homebuyers. The raising of funding for both these activities has never been a problem in the country but the financial institutions carrying out such lending have been subject to varying controls by the Central Bank of Malaysia. The selective control of credit in rapid monetary expansion can provide a temporary relief to the housing and finance markets. In this respect, it appears that many financial institutions in the country still have a sizeable capacity in providing such loans in the market.
Furthermore, if overall credit continues to expand further, then there should be more opportunities for financing within the housing market.

The housing finance system plays a central role in the housing market as the willingness and capacity of the financial institutions to lend tends to boost house prices. For such relationship, an increase in the price of housing may increase the supply of credit to the housing market, or vice versa. Such hypothesis has been debated among real estate and financial economists across East Asian countries with particular emphasises on real estate cycles and banking crises (Herring, Wachter 1999), the relationship between the real estate market and the financial sector (Hilbers et al. 2001) and linkages between lending booms, real estate price cycles and financial crises (Collyn, Senhadji 2002). However, to date none of the studies in Malaysia has focused on the inter-relationship between housing markets and housing finance systems.

In order to gain more insight into the interrelationship between the housing market and the housing finance system, models for both the Malaysian housing market and housing finance system will be developed in this paper. This paper empirically identifies the inter-relationship between the housing market and the housing finance system and is organised as follows. First, the Malaysian housing market and housing finance system are discussed. The main discussion in this section is to examine the housing market and the housing finance system in Malaysia, in order to provide the context concerning the development and operation of both markets. In the next section, relevant literature to this research are discussed. Then, follows the discussion on data and research methodology including the empirical analysis. Thereafter, summary and conclusions based on empirical modelling are discussed.

\section{MALAYSIAN HOUSING MARKET AND HOUSING FINANCE SYSTEM}

\subsection{Malaysian housing market}

The housing market in Malaysia involves four main players namely the government, developers, purchasers and bankers. Generally, the government is responsible for formulating housing policies and regulatory frameworks (Agus 1997). In achieving the government housing target to provide shelter to its citizens, especially for low income groups to own a house, private developers have engaged in the Malaysian housing provision and thus play an 
important role in the supply side of the housing market. This provides an opportunity for private developers to get involved in housing development by allocating the development area via development plans, such as structural or local plans.

However, land in Malaysia is a state matter, thus the supply of land for housing falls under the jurisdiction of local authorities of the particular state. The success of any housing project is also dependent on other market players; homebuyers and bankers. Banks and financial institutions normally provide two categories of loans in the Malaysian housing market; bridging and end finance. Bridging finance is used as a capital injection to start housing construction whilst end financing is for homebuyers to buy a housing unit. Therefore, the successful operation of the housing market is subjected to the involvement of relevant parties in the housing market.

The housing market is linked to three tiers of government namely federal, state and local government supported by traditional regulatory housing policies. At a national level, the Ministry of Housing and Local Government plays a vital advisory role in formulating housing policies and the framework for housing development. This focuses on the allocation of land, population density, layout plans and physical housing development. In order to ensure a smooth implementation of housing policies and strategies, the Ministry hosts a number of councils and forums to strengthen cooperation between the public and private sectors in the housing industry. The Ministry also establishes future direction of housing needs in a national development plan by setting up a number of units targeted for each plan. The plan is revised every five years emphasising housing strategies and programmes. The implementation of the housing programmes has been established through various legislation, public institutions and instruments.

\subsection{Malaysian housing finance}

A healthy housing industry is critical to the nation's economy and more specifically the sustainability of its financial system. The government's main intention is to provide affordable shelter to its citizens and a certain percentage of lending by financial institutions is channelled to the housing industry. Thus, the sustainability of the housing market is critical since its operation depends on money supply conditions and credit availability. Easy access to housing finance smoothes the progress of housing market activities. However, re- laxation of monetary conditions may provide excessive liquidity to financial institutions and in return leads to house price inflation. The lack of credit availability provides an impact on the demand for housing units and hence, slows down the housing market activity. Excessive supply of housing finance, on the other hand, may causes escalation of house prices, in return creates glut and an oversupply situation in the housing market. Hence, housing finance is often used as an instrument to boost the nation's economy during recession and to regulate the economy during recovery period. Warnock and Warnock (2008) shows that Malaysia has the preeminent housing finance system in the emerging Asia countries.

Financial institutions are involved in lending to both the construction sector and for the purchase of housing units. In most cases, project financing is highly dependent on purchaser-generated funds created from the $10 \%$ deposit paid to the developers and the bank loans approved to the purchasers. However, most developers apply for project financing from banks at the early stage of development in order to cover the initial cost of infrastructure and working capital. Once the purchaser-generated funds have been released through progress payment, the fund will be used by the developers to pay their debt to the bank. The rate of sales for any newly launched project is crucial in determining the project's success both for the project financing and end financing.

Most of the prospective purchasers rely on the end finance to purchase a housing unit. Since owning a housing unit is every citizen's dream, coupled with promising economic situation, housing credit institutions in Malaysia have been channelling funds to help the homebuyers (BNM 2007). Housing credit institutions comprise commercial banks (provides housing loans to public at large), Treasury Housing Loans Division (provides housing loans to government employees), Bank Kerjasama Rakyat Malaysia Berhad (mobilises saving and provides housing loans to both its member and non-members), Malaysia Building Society Berhad (provides housing loans and deposit taking activities to public at large), Borneo Housing Mortgage Finance Berhad (provides housing loans to Sabah and Sarawak Government employee), Bank Simpanan Nasional (provides personal finance to public at large), and Sabah Credit Corporation (provides easy access to financial credit to Malaysian citizen in the state of Sabah). Commercial banks were the main providers of housing loans for the period 1993-2010 with a market share of more 
Table 1. Housing Credit Institutions (market share of approved housing loans)

\begin{tabular}{lllllll}
\hline HCI/Year & $1993-1995$ & $1996-1998$ & $1999-2001$ & 2002-2004 & 2005-2007 & 2008-2010 \\
\hline Commercial Banks & 81.32 & 86.42 & 85.33 & 82.78 & 83.43 & 87.95 \\
Treasury Housing Loans Division & 13.51 & 8.86 & 11.23 & 12.92 & 10.05 & 8.85 \\
Malaysia Building Society Berhad & 3.36 & 1.05 & 0.98 & 1.69 & 2.71 & 1.70 \\
Borneo Housing Mortgage Finance Berhad & 0.55 & 0.49 & 0.32 & 0.24 & 0.14 & 0.08 \\
Sabah Credit Corporation & 0.24 & 0.22 & 0.09 & 0.05 & 0.02 & 0.01 \\
Bank Kerjasama Rakyat Malaysia Berhad & 0.93 & 0.84 & 1.21 & 1.89 & 1.65 & 0.36 \\
National Savings Bank & 0.09 & 2.12 & 0.85 & 0.41 & 2 & 1.06 \\
Total & 100 & 100 & 100 & 100 & 100 & 100 \\
\hline
\end{tabular}

than $80 \%$, followed by Treasury Housing Loans Division (Table 1). The former's approved housing loans increased from RM28,736 million (USD9,579 million) in 1993-1995 to RM200,204 (USD66,735 million) million in 2008-2010, whereas the latter increased from RM4,503 million (USD1,501 million) to RM19,757 million (USD6,586 million) for the same corresponding periods.

In the public sector, the Treasury Housing Loans Division is the principal source for housing loans in Malaysia. At the end of 1990, the market share of the Treasury for the outstanding housing loans stood at $39.9 \%$ of the total outstanding housing loans but decreased to $12.8 \%$ by the end of 2006 (BNM 1991; 2007). The market share of the Treasury for approved housing loans accounted for $20.9 \%$ of the total approved housing loans at the end of 1990 but decreased to $12.8 \%$ at the end of 2006 (BNM 1991; 2007). In the private sector, commercial banks dominate the housing market with the market share of approved housing loans at $50.3 \%$ in 1990 (BNM 1991) increasing to $82 \%$ in 2006 (BNM 2007).

\section{LITERATURE REVIEW}

Access to funds and the availability of funds are very important to housing development. Easy access to housing finance encourages developers to venture into new housing developments to reap more profit without prudent market study. As a consequence, more developers were faced with cash flow problems during the market downturn resulting in higher non-performing loans in the banking industry. As for the housing purchasers, many borrowers failed to trade off their unit to pay off the loan. There are two reasons for such problems; firstly, the bank had tightened up lending policy which discouraged potential buyers to purchase a housing unit; and secondly, many borrowers found that they were in negative equity as a result of their loan value exceeded the existing housing value. The non-performing loans for the purchase of residential property by commercial banks alone stood at RM6,682 million (USD2,135 million) as at the end of 2002 and increased to RM13,746 million (USD4,392 million) at the end of 2005 . The former represented $14.7 \%$ of the total non-performing loans in the market economy whereas the latter about $30.0 \%$ (BNM 2008). The excessive supply of credit was the potential source of instability to the housing finance system. Compared to its neighbouring countries, Malaysia followed the same trends exhibited by Singapore and Indonesia for overall bank non-performing loans as measured from the total commercial bank loans (Fig. 1).

The question of homogeneity and heterogeneity in the housing market is a crucial problem in relation to market efficiency (Barkham, Geltner 1996; Evans 1995). Imperfect information, supply rigidities and imperfect financial markets further

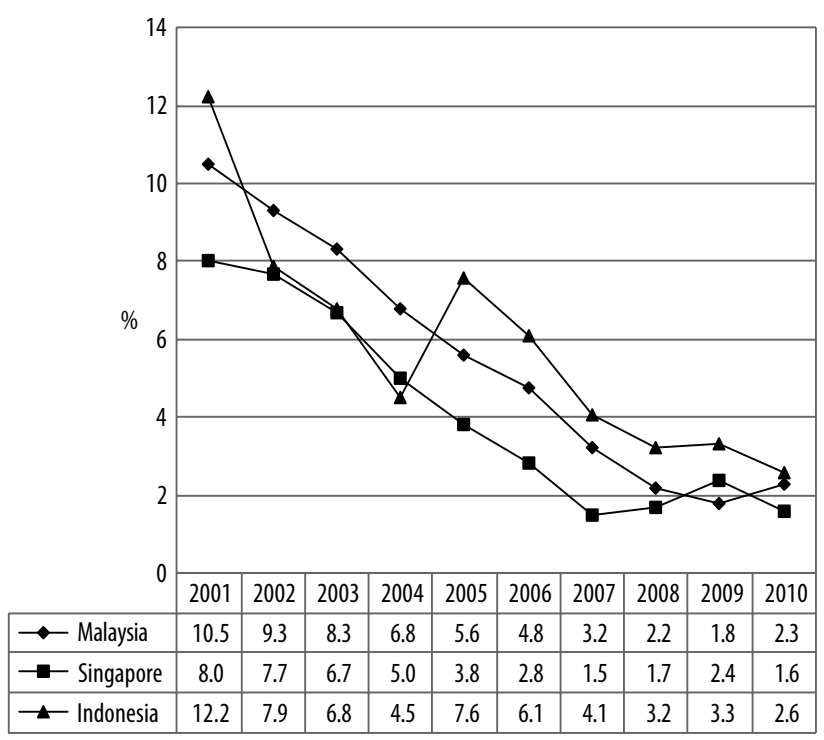

Fig. 1. Non performing loans at selected South East Asian countries (\% of commercial bank loans) Source: Asian Development Bank (2013) 
contribute to the inefficiency of the market particularly longer periods in which actual prices may deviate from their actual value (Collyns, Senhadji 2002; Herring, Wachter 1999).

The structure and performance of the housing market have been widely cited as causal factors in the economy (Maclennan et al. 1998; Muellbauer, Murphy 1997; Stevenson 2000; Apergis 2003). Housing markets often appear as an enigma in terms of quantity and price dynamics which are difficult to reconcile with the housing finance system (Iacoviello, Minetti 2000; Tse 2004). Furthermore, housing markets have been characterised by striking booms and busts in prices (Muelbauer, Murphy 1997; Case, Shiller 2003) and monetary policy has generally been considered a secondary factor in this dynamic (Iacoviello, Minetti 2000). Under normal market conditions, the housing market may be influenced by changes in bank lending criteria during certain periods as well as other factors such as disposable household income, consumer's expenditure, mortgage interest rates, demographic developments and the housing stock (Muelbauer, Murphy 1997; Case, Shiller 2003; DiPasquale, Wheaton 1994; Pain, Westaway1997). As for housing loans, these may be dependent on house prices as well as disposable income (Adair et al. 1998, 2001).

In addressing the above issues, Iacoviello and Minetti (2000) argued in their analysis for four countries namely Finland, the United Kingdom, Germany and Norway that investment in residential housing is highly dependent on the efficiency of housing finance. A study by Nadler (2005) evaluates housing finance systems in Germany, Denmark and the USA. In his study, three parties involved in the process of financial intermediation have been evaluated namely borrowers, lenders and governments. The evaluation found that the priority of each party varies from one country to another. A more specific study on the East Asian countries namely Hong Kong, Korea, Singapore and Thailand, conducted by Collyn and Sedhaji (2002), assessed the interaction between credit growth and real estate prices and found that the response of property prices to credit is asymmetric in the sense that the response during periods of rising property prices is three time the response during periods of declining prices. Other relevant literature concerning the interaction between the two markets has focussed on, among others, the efficiency of the housing finance system (Lea 1994), implications on social and economic activities (Stephens 2003) and differences in housing and financial markets (MacLennan et al. 1998).
In a recent study, Gupta et al. (2012) applied the Bayesian Vector Autoregressive Model to identify the relationship between Federal funds rate and the US housing sector. The outcome of their analysis shows that variables in housing market fall in response to the tightening of monetary policy. Furthermore, a study by Hepsen and Vatansever (2012) was conducted to identify the relationship between the house price index and macroeconomic variables in Dubai. Hepsen and Vatansever (2012) found that there is a long term positive equilibrium relationship between the Dubai Property Price Index (DRPPI) and gold price as well as with the total volume of total direct foreign trade. The outcomes of their study also show a significant positive relationship between the DRPPI and the first lag of DRPPI. In addition, Holstein et al. (2013) found that the lagged values of household debt and foreign direct investment are significant predictors of movements in the income/home price ratio. This study has been conducted in the United States to find the determinants of the income/home price ratio. It is clear that many studies have attributed to the importance of inter-relationship between the housing and financial markets. However, there is a big literature gap locally where no study has been conducted to determine the relationship between housing market and the housing finance system. The study is crucial in justifying the robustness of the housing finance system in relation to the performance of housing market over time. In this paper, we will look into such relationship to determine the effect of changes in housing market on the housing finance system and vice versa. Although the identified variables have been used in the past studies, we have differentiated all the variables to represent each submarket within the housing finance system (see Table 2).

\section{DATA AND METHODOLOGY}

This study develops models to deal with the interaction of the Malaysian housing market and the housing finance system. The interaction between the housing market and housing finance system may take different forms in which the responses of market changes may run from housing finance systems to the housing market or vice versa. In modelling such relationships, several models are developed adopting an economic and finance framework known as Vector Autoregressive (VAR) approach together with Granger Causality test. This framework is widely used and accepted by international 
researchers to identify relationship between variables in the real estate markets (Brooks 2008; Koop 2008; Gupta et al. 2012; Hepsen, Vatansever 2012; Holstein et al. 2013). We will therefore use the same framework to evaluate the relationship between the housing market and housing finance system in Malaysia.

The methodology is structured as follows. Sections 4.1 and 4.2 discuss approaches to the analysis involving detection of stationarity and transformation of variables. The discussion focuses on the identification of unit root (stationarity) for each individual series prior to developing a dynamic regression model involving several series. The main contribution concerning time series modelling is to provide a better understanding of how the housing market and housing finance system interact over time, through the application of appropriate techniques. We found that, most local researchers in the past blindly applied time series variables without going through the process of selecting these techniques. Therefore, this subsection discusses the approach and concept of time series modelling and develops relevant models to justify the relationship between the housing market and the housing finance system.

\subsection{Detection of stationarity}

The general rule in time series analysis is a regression model cannot be run for non-stationary time series (Philips 1986; Koop 2008). The appropriate route of running time series regression is to transform the variables to make them stationary. Therefore, the first step (formal method) is to test for a unit root in order to check for the stationarity of the variables. If $y$ and $x$ contains unit roots then the regression estimation can generate a wrong result (spurious regression problem). The letter " $y$ " used in the discussion referred to the housing market variable whereas " $x$ " refers to the housing finance variables. If these variables have unit roots then differences have to be taken to make them stationary. Thus, the presence of unit roots is tested as a basis from running time series regression. The most commonly used methods in testing the unit roots are the Dickey-Fuller (DF) (Dickey, Fuller 1979) and Augmented Dickey Fuller (ADF) (Dickey, Fuller 1981) tests.

The DF method is developed to test $\rho=0$ or $\Phi=1$, where $\rho$ or $\Phi$ is a regression coefficient. The method is based on the autoregressive (AR) model with independent (exogenous) variable being the dependent (endogenous) variable lagged one peri- od. This is also called as AR(1) model. The basis of the AR (1) model is Ordinary Least Square (OLS) methodology except that the independent variable is the same variable lags of itself as shown in the following model:

$$
y_{t}=\alpha+\Phi y_{t-1}+e_{t},
$$

where: $\alpha=$ intercept; $\Phi=$ estimate on the first lagged $y$ variable; $e_{\mathrm{t}}=$ white noise (error) for the equation

The model implies that if $\Phi=1$, then $y$ is nonstationary whereas if $\Phi<1$ then $y$ is stationary. Therefore, $y$ has a unit root if $\Phi=1$. If $y$ has a unit root, then $\Delta y$ will be stationary.

The DF method is further developed by subtracting $y_{t-1}$ from both sides of the equation to establish the so-called random walk model, as follows:

$$
\Delta y_{t}=\alpha+\rho y_{t-1}+e_{t},
$$

where: $\rho=\Phi-1$, and therefore if $\Phi=1$, then $\rho=$ 0 . If $\Phi=1$ (or $\rho=0$ ), the AR (1) model (equation $1)$ is written as:

$$
y_{t}=\alpha+y_{t-1}+e_{t} .
$$

If natural logarithms are used to log variables, then the random walk model is known as a random walk with drift. The log of $y$ creates a random walk with drift which can be written as:

$$
y_{t}-y_{t-1}=\alpha+e_{\mathrm{t}},
$$

where: $y_{t}-y_{t-1}$ is equivalent to the percentage change in $\mathrm{y}$, in turn equivalent to $\alpha$ (a benchmark increase in variable $y$ ) plus a random error.

The random walk model is used as a basis of the DF test (based on t-statistic); $\Phi=1(\rho=0)$ implies that $y$ has a unit root and is stationary. If $y$ has a unit root in the random walk model, it is known as I(1) series. However, if $y$ doesn't have a unit root (stationary), it is known as $\mathrm{I}(0)$ series. The DF model is further extended for testing stationary especially if $\rho$ is not statistically different from zero. In this case, the so-called AR(p) with deterministic trend model is used especially if certain explanatory variables need to be omitted for a final regression model. The main difference with $\operatorname{AR}(1)$ model is the " $p$ " used in the AR(p) model refers to extra lags in the model. Economists always refer to DF test for testing for $\rho=0$ in the AR(1) model and the ADF test for testing in the AR(p) model. In the $\mathrm{AR}(\mathrm{p})$ model, the unit root test is "augmented" with extra lags. In other words, the idea of ADF 
is to test the null hypothesis of $\rho=0$ against the alternative hypothesis of $\rho<0$ which is based on the coefficient ( $\rho$ ) of equation (2). Hence, this concept is used for testing unit root for variables in the housing market, the housing finance system and macroeconomic variables.

\subsection{Transformation of variables}

As discussed above, the unit root test is used as the first step in implementing the time series regression. If variables are non-stationary, they need to be differenced to make them stationary. The common approach used in dealing with nonstationary time series is natural logarithm as a form of transformation in the analysis. The basis of natural logarithm is $\log _{\mathrm{e}}(\mathrm{A})=\ln (\mathrm{A})$ (Koop 2008). In this case, the logarithm (to the base $e$ ) of a number, A, is the power of $e$ to be raised to give A. Using this approach, the percentage change in a variable is approximately $100 X\left[\ln \left(y_{t}\right)-\ln \left(y_{t-1}\right)\right]$. The percentage change in this case represents more or less the same figure as annual percentage change. Hence the concept of natural logarithm is used especially to test for a unit root on each variable and the percentage change ( $\Delta y$ or $\Delta x)$ is obtained by differencing the log variables. However, the actual figures are used for certain variables instead of using natural logarithm, especially variables which do not need interpretation in terms of percentage change (return).

The first step taken in transforming the potential variables was to list them according to the groups or sub-groups they belong to. The two groups are identified as the housing market and the housing finance system. The name and sym- bol of raw datasets are given to each variable (Table 2). The establishment of such groups helps to identify the analysis of the relationship between the housing market and housing finance system (primary mortgage market, secondary mortgage market and capital market). All the variables in monetary forms have been transformed to real values.

Since the rules of OLS estimation implicitly assume that the independent (explanatory) variables must not be correlated with one another (Brooks 2008), the next step is to filter and remove these out, if the correlation appears to be high. The literature suggests that the rules of thumb imply that $0.75 \%$ and above are considered high in getting rid of multicollinearity. Brooks (2008) groups multicollinearity into two, namely perfect and near multicollinearity. Perfect multicollinearity occurs when the relationship between one or more variables is found to have an exact relationship between them whereas the near multicollinearity (unavoidable in practice) occurs when a non-perfect relationship exists. Therefore, the explanatory variables with significant correlation were eliminated and the new variable list tested for stationary conditions prior to implementing the time series regression.

The unit root test was conducted using the ADF model (with intercept, intercept with trend or none of them) in finding stationary conditions. Furthermore, the use of various cases are subject to graphical check: none (if the time-series is flat with potential slow-turning around zero); intercept (if the time-series is flat with potential slow-turning around non-zero); and intercept and trend (if the time series has a trend with potential slow-

Table 2. List of potential variables for time series modelling

\begin{tabular}{|c|c|c|c|}
\hline Symbol & Raw data name & Sub-group & Main group \\
\hline MPI & Malaysian House Price Index & \multirow{9}{*}{$\begin{array}{l}\text { Primary } \\
\text { mortgage } \\
\text { market }\end{array}$} & \multirow{4}{*}{$\begin{array}{l}\text { Housing } \\
\text { market }\end{array}$} \\
\hline VOT & Volume of transaction (units) & & \\
\hline HAP & Approved housing units (number) & & \\
\hline HST & Housing stock (unit) & & \\
\hline ALCB & Real approved housing loans by commercial banks (RM million) & & \multirow{8}{*}{$\begin{array}{l}\text { Housing } \\
\text { finance } \\
\text { system }\end{array}$} \\
\hline HIAL & Real approved housing loans by HCI (RM million) & & \\
\hline HIOL & Real outstanding housing loans by HCI (RM million) & & \\
\hline NPL & Real non-performing loans (RM million) & & \\
\hline OLCB & Real outstanding housing loans by commercial banks (RM million) & & \\
\hline CALCB & Real housing loans sold to Cagamas by commercial banks (RM million) & \multirow{2}{*}{$\begin{array}{l}\text { Secondary } \\
\text { mortgage } \\
\text { market }\end{array}$} & \\
\hline CAS & Real Housing loans securitised by Cagamas (RM million) & & \\
\hline KLCI & Kuala Lumpur Composite Index & Capital market & \\
\hline
\end{tabular}

Note: Cagamas refers to the National Mortgage Corporation which is the only entity operating the Malaysian secondary mortgage market. 
turning around the trend line). The test uses a 5\% critical value. The software used in the analysis is Eviews version 6.

Table 3 shows the result obtained from the ADF test on the assumption that all variables have an intercept but do not have trends in them. The results show that most variables are in I(1) conditions and differencing is needed to make these variables stationary. Using the same assumption that the variables tend to have intercept and trend, certain variables resulted in $\mathrm{I}(2)$ conditions (L_MPI, L_HAP and L_KLCI) and therefore need for second differences to make them stationary (Table 4).

\section{EMPIRICAL RESULTS}

This section investigates the interaction of the housing market and the housing finance system involving the lead-lag relationship. For this purpose the VAR approach is adopted for modelling such relationship. The occurrence of shock to one variable may generate responses to other markets. Therefore, this approach was employed in establishing models to deal with lead-lag relationship, impulse responses and the variance decomposition due to the market shock. The models developed through the approach are used to find the direction of causality between the housing market and the housing finance system

Vector autoregressive (VAR) was popularised by Sims (1980) as a univariate autoregressive model to measure the lead-lag relationship in the long-run. In addition, the model provides a framework for testing Granger Causality between variables. The rationale of the model is that it treats all the variables as endogenous and allows them to depend on the previous values of lags, plus an error term. A VAR can be considered as a hybrid between the univariate time series and the simultaneous structural equations.

A VAR model may take the following form:

$$
\begin{aligned}
& y_{\mathrm{t}}=\alpha_{1}+\delta_{1 t}+\Phi_{11} y_{t-1}+\ldots \Phi_{1 \mathrm{k}} y_{t-k}+ \\
& \beta_{11} x_{t-1}+\ldots+\beta_{1 \mathrm{p}} x_{t-\mathrm{p}}+u_{1 t}, \\
& x_{t}=\alpha_{2}+\delta_{2 t}+\Phi_{21} y_{t-1}+\ldots \Phi_{2 \mathrm{k}} y_{t-k}+ \\
& \beta_{21} x_{t-1}+\ldots+\beta_{2 \mathrm{p}} x_{t-\mathrm{p}}+u_{2 t},
\end{aligned}
$$

where: $u_{1 \mathrm{t}}$ is a white noise.

Equations (5) and (6) can be differentiated in terms of $y$ depends on $\mathrm{k}$ lags of itself and on $\mathrm{p}$ lags of $x$. The optimal lag lengths for a VAR can be based on VAR information criterion using the likelihood ratio (LR) test. The estimation of VAR model can be done in a standard way where the

Table 3. Augmented Dicker-Fuller unit-root test (intercept without trend)

\begin{tabular}{llllll}
\hline Symbol & Transformed variables & t-statistic & Prob. & 5\% critical value & Unit root \\
\hline L_MPI & Nat.log of MPI & -2.7660 & 0.0852 & -3.0656 & $\mathrm{I}(1)$ \\
L_VOT & Nat.log of VOT & -1.7220 & 0.4042 & -3.0404 & $\mathrm{I}(1)$ \\
L_HAP & Nat.log of HAP & -3.4247 & 0.0269 & -3.0810 & $\mathrm{I}(0)$ \\
L_HST & Nat.log of HST & -2.9812 & 0.0559 & -3.0404 & $\mathrm{I}(1)$ \\
L_ALCB & Nat.log of ALCB & -3.6696 & 0.0519 & -3.6908 & $\mathrm{I}(1)$ \\
L_HIAL & Nat.log of HIAL & -0.8314 & 0.7855 & -3.0404 & $\mathrm{I}(1)$ \\
L_CALCB & Nat.log of CALCB & -1.4455 & 0.5371 & -3.0404 & $\mathrm{I}(1)$ \\
L_CAS & Nat.log of CAS & -2.8518 & 0.0710 & -3.0404 & $\mathrm{I}(1)$ \\
L_KLCI & Nat.log of KLCI & -2.8695 & 0.0687 & -3.0404 & $\mathrm{I}(1)$ \\
\hline
\end{tabular}

Table 4. Augmented Dicker-Fuller unit-root test (intercept with trend)

\begin{tabular}{llllll}
\hline Symbol & Transformed variables & t-statistic & Prob. & 5\% critical value & Unit root \\
\hline L_MPI & Nat.log of MPI & -2.1499 & 0.4845 & -3.7105 & $\mathrm{I}(2)$ \\
L_VOT & Nat.log of VOT & -3.4133 & 0.0809 & -3.6908 & $\mathrm{I}(1)$ \\
L_HAP & Nat.log of HAP & -0.3376 & 0.9818 & -3.6908 & $\mathrm{I}(2)$ \\
L_HST & Nat.log of HST & -1.4843 & 0.7966 & -3.6908 & $\mathrm{I}(1)$ \\
L_CALCB & Nat.log of CALCB & -2.0029 & 0.5608 & -3.6908 & $\mathrm{I}(1)$ \\
L_HIAL & Nat.log of HIAL & -4.2132 & 0.0194 & -3.6908 & $\mathrm{I}(0)$ \\
L_CALCB & Nat.log of CALCB & -2.0029 & 0.5608 & -3.6908 & $\mathrm{I}(1)$ \\
L_CAS & Nat.log of CAS & -3.0716 & 0.1419 & -3.6908 & $\mathrm{I}(1)$ \\
L_KLCI & Nat.log of KLCI & -2.7617 & 0.2269 & -3.6908 & $\mathrm{I}(2)$ \\
\hline
\end{tabular}


value of coefficients is determined using the OLS. In using the VAR model, all the variables must be in $\mathrm{I}(0)$ conditions. Thus, the first step in using the VAR approach is to test variables for stationary (Table 5). DL_MPI represents the housing market variable, the housing finance system is presented by DL_HIAL (primary mortgage market), DL_CAS (secondary mortgage market and DL_KLCI (capital market).

Table 5. Augmented Dicker-Fuller unit-root test (without trend)

\begin{tabular}{lllll}
\hline Symbol & t-statistic & Prob. & $\begin{array}{l}5 \% \text { critical } \\
\text { value }\end{array}$ & Unit root \\
\hline DL_MPI & -3.1274 & 0.0447 & 0.0447 & $\mathrm{I}(0)$ \\
DL_HIAL & -6.1059 & -3.0522 & 0.0001 & $\mathrm{I}(0)$ \\
DL_CAS & -6.4941 & -3.0522 & 0.0001 & $\mathrm{I}(0)$ \\
DL_KLCI & -4.6605 & -3.0522 & 0.0022 & $\mathrm{I}(0)$ \\
\hline
\end{tabular}

The application VAR has yielded the following models:

\section{Model 1}

$$
\begin{aligned}
& \Delta \mathrm{L} \_\mathrm{MPI}=0.0459+1.3753 \Delta \mathrm{L} \_\mathrm{MPI}{ }_{t-1}- \\
& 0.7698 \Delta \mathrm{L} \_\mathrm{MPI}_{t-2}-0.2078 \Delta \mathrm{L}_{-} \mathrm{HIAL}_{t-1}- \\
& 0.1525 \Delta \mathrm{L} \_\mathrm{HIAL}_{t-2}+0.0030 \Delta \mathrm{L}_{t} \mathrm{CAS}{ }_{t-1}^{+} \\
& 0.0163 \Delta \mathrm{L} \_\mathrm{CAS}{ }_{t-2}+0.0040 \Delta \mathrm{L} \_\mathrm{KLCI}_{t-1}^{+} \\
& 0.0587 \Delta \mathrm{L} \_\mathrm{KLCI}_{t-2}
\end{aligned}
$$

\section{Model 2}

$$
\begin{aligned}
& \Delta \mathrm{L} \_\mathrm{HIAL}=0.2164+2.6073 \Delta \mathrm{L} \_\mathrm{MPI}_{t-1}- \\
& 3.0707 \Delta \mathrm{L} \_\mathrm{MPI}_{t-2}-0.8599 \Delta \mathrm{L} \_\mathrm{HIAL}_{t-1}- \\
& 0.1192 \Delta \mathrm{L}_{-} \mathrm{HIAL}_{t-2}+0.1115 \Delta \mathrm{L}_{-} \mathrm{CAS}_{t-1}+ \\
& 0.0077 \Delta \mathrm{L}_{-} \mathrm{CAS}_{t-2}+0.3829 \Delta \mathrm{L} \_\mathrm{KLCI}_{t-1}- \\
& 0.1285 \Delta \mathrm{L} \_\mathrm{KLCI}_{t-2}
\end{aligned}
$$

\section{Model 3}

$$
\begin{aligned}
& \Delta \mathrm{L} \_\mathrm{CAS}=0.0642-1.5957 \Delta \mathrm{L} \_\mathrm{MPI}_{t-1}+ \\
& 0.9693 \Delta \mathrm{L} \_\mathrm{MPI}_{t-2}+0.3250 \Delta \mathrm{DL} \_\mathrm{HIAL}{ }_{t-1}- \\
& 0.0473 \Delta \mathrm{L} \_\mathrm{HIAL}_{t-2}-0.3214 \Delta \mathrm{L} \_\mathrm{CAS}_{t-1}+ \\
& 0.0772 \Delta \mathrm{L} \_\mathrm{CAS}_{t-2}+0.7893 \Delta \mathrm{L} \_\mathrm{KLCI}_{t-1}- \\
& 0.2197 \Delta \mathrm{L} \_\mathrm{KLCI}_{t-2}
\end{aligned}
$$

\section{Model 4}

$$
\begin{aligned}
& \Delta \mathrm{L} \_\mathrm{KLCI}=0.1653+4.8835 \Delta \mathrm{L} \_\mathrm{MPI}_{t-1}- \\
& 2.6734 \Delta \mathrm{L} \_\mathrm{MPI}_{t-2}-1.3564 \Delta \mathrm{L} \_\mathrm{HIAL}{ }_{t-1}- \\
& 0.8509 \Delta \mathrm{L} \_\mathrm{HIAL}_{t-2}+0.1040 \Delta \mathrm{L}_{\mathrm{C}} \mathrm{CAS}_{t-1}+ \\
& 0.0678 \Delta \mathrm{L} \_\mathrm{CAS} \mathrm{t}_{t-2}-0.6975 \Delta \mathrm{L} \_\mathrm{KLCI}_{t-1}- \\
& 0.1917 \Delta \mathrm{L} \_\mathrm{KLCI}_{t-2}
\end{aligned}
$$

The relationship among variables within Models (1) to (4) is explained through impulse responses (Subsection 5.1), variance decomposition (Subsection 5.2) and Granger causality test (Subsection $5.3)$.

\subsection{Impulse responses}

Impulse responses refer to a shock to the error of a particular equation where other equations are being held constant (Sims 1980; Brooks 2008). The function of impulse responses is to find the responsiveness of the explained variable to a shock to each of the explanatory variables. So, a unit shock for each variable is applied to the error which effects the overall equation over time. Therefore, the effects of shocks as a result of interactions between equations in the VAR system can be justified through orthogonalised impulse responses. The isolation effect of market responses is shown in the form of Cholesky innovations, along with \pm 2 times standard deviation of the shock. Fig. 2(A) to (P) show asymptotic format of the impulse responses for innovation in unexpected errors for Models 1 to 4 for a period of ten years.

The response of the housing market as a result of a shock to housing finance system is shown in Fig. 2(B) as a response to a shock in primary mortgage market, $2(\mathrm{C})$ in secondary mortgage market and $2(\mathrm{D})$ in the capital market. For example, Fig. 2(B) shows a response of the housing market to a shock in the primary mortgage market as represented by housing loans approved by housing finance institutions (DL_HIAL). The result indicates that as the number of approved housing loans decreases, the demand for housing decreases, and in turn pushes the house price downwards. A shock to approved housing loans leads to a decline in house price, then reaches a steady-state level after four years, after which the price drops again. The rest of Fig. 2 individually shows responses to a shock either within the housing market itself, or between the sub-markets within the housing finance system.

\subsection{Variance decomposition}

Variance decomposition determines the effect of each variable to the other variables as a result of shocks within the VAR system. In other words, variance decomposition indicates the level of information (the forecast error variance) each variable contributes to the other variables. Table 6 reports the forecast error of house price variance and its proportion of contribution to random shock to each housing finance variable. The results suggest that, within a year, shocks to changes in Cagamas's securitisation of housing loans (DL_CAS) accounts the highest variation (53.2\%) in house price change, followed by changes in the house price itself (24.0\%). However, changes in the Kuala Lumpur Composite 
Response to Cholesky One S.D. Innovations $2 \pm$ S.E
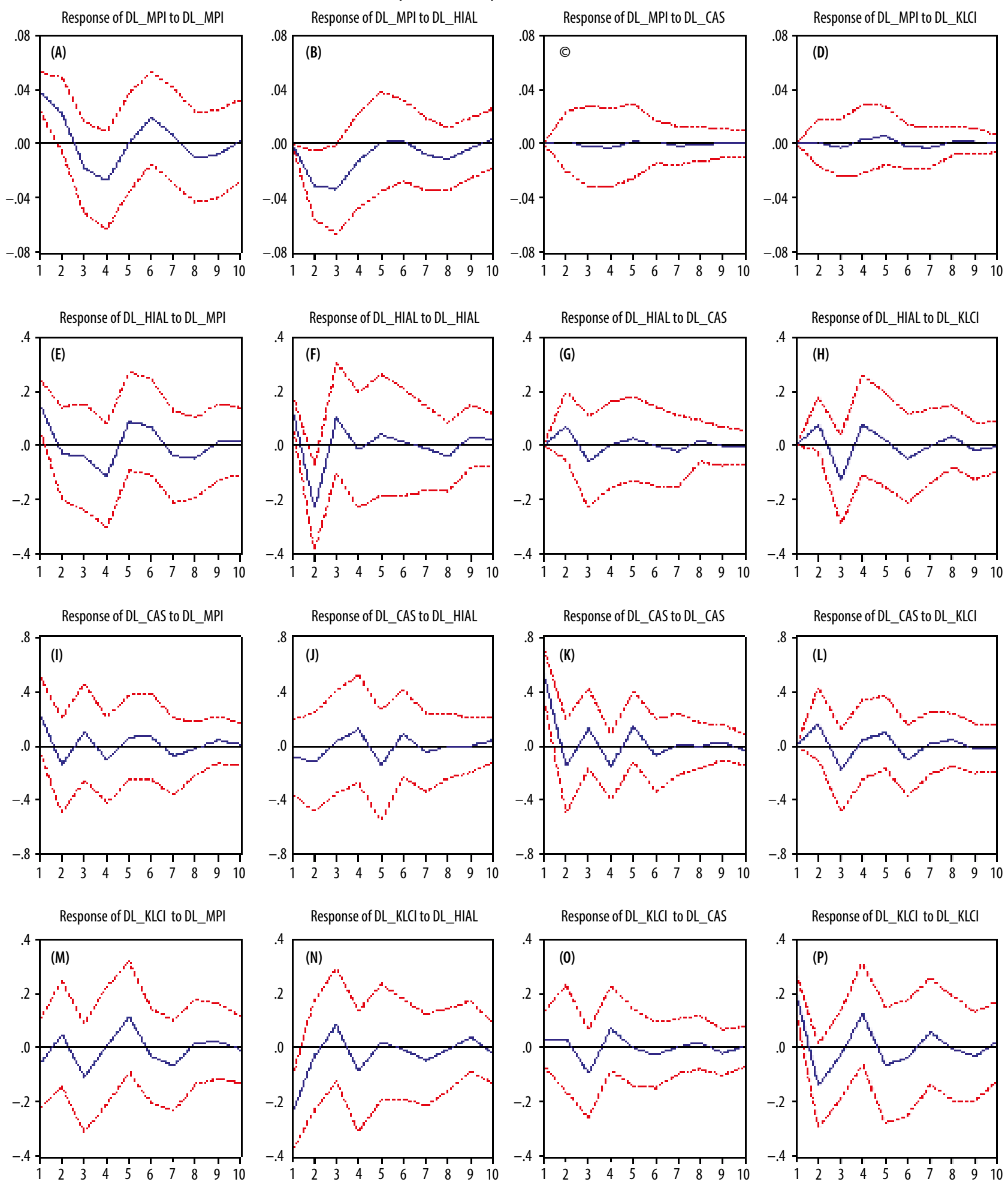

Fig. 2. Impulse response for innovations in unexpected equation errors

Index (DL_KLCI) do not contribute to variation in house price during the same period. Changes in approved housing loans by housing credit institutions (DL_HIAL) provide a negative reaction $(-8.0 \%)$ to variation in house price. Clearly, changes in the capital market constitute the highest explanatory power in explaining the variability of changes in the house price over a year. Over a longer period, up to ten years, the shock to the primary mortgage market provides the greatest contribution to house price variation. However, the capital market $(-2.3 \%)$ and the secondary mortgage market $(-3.0 \%)$ influences the housing market negatively in ten years' time. 
Table 6. Variance decomposition of housing price

\begin{tabular}{lcccc}
\hline Year & DL_MPI & DL_HIAL & DL_CAS & DL_KLCI \\
\hline 1 & 0.2397 & -0.0799 & 0.5329 & 0.0000 \\
2 & -0.1395 & -0.1234 & -0.1464 & 0.1589 \\
3 & 0.1022 & 0.0335 & 0.1281 & -0.1824 \\
4 & -0.1043 & 0.1210 & -0.1542 & 0.0435 \\
5 & 0.0633 & -0.1459 & 0.1433 & 0.0983 \\
6 & 0.0668 & 0.0910 & -0.0726 & -0.1097 \\
7 & -0.079 & -0.0495 & 0.0105 & 0.0189 \\
8 & -0.0216 & -0.0015 & -0.003 & 0.0440 \\
9 & 0.0410 & -0.0008 & 0.0230 & -0.0218 \\
10 & 0.0077 & 0.0403 & -0.0305 & -0.0233 \\
\hline
\end{tabular}

\subsection{Direction of causality}

Correlation analyses do not necessarily provide meaningful causation between variables. The direction of the causal relationship between the housing market and the housing finance systems is tested for using Granger-causality.

The Granger-causality test establishes the relationship between variables on the notion that the past may cause the future, but the future cannot cause the past (Granger 1969). In the context of the Malaysian housing market and housing finance system, the direction of causality is not clear; therefore it is necessary to test for causal directions between them. Hence, the housing finance systems (x) Granger-cause the housing market (y) if it can be established that the past value of $x$ and $y$ is statistically significant on future value of $y$.

The directions of causality are tested to establish the possibility of the followings:

i. No causality between $x$ and y;

ii. Unidirectional causality; $y$ is causing $x(y \rightarrow x)$; iii. Unidirectional causality; $x$ is causing $y(x \rightarrow y)$; iv. Bidirectional causality; $y$ is causing $x$ and $x$ is causing $y(y \leftrightarrow x)$.

The VAR approach is adopted in identifying any causal relationship between the housing finance system and housing market. The rationale of using VAR is that if the housing market and the housing finance system have lead-lag relationships, then Granger causality must occur in some forms. VAR was used to test whether the housing finance system Granger-cause the housing market or vice versa by reversing the roles that the housing finance system and the housing market play in the VAR system.

The results of VAR Granger causality test for variables having lead-lag relationship are based on Models (1) to (4) above. The overall results (Fig. 3)

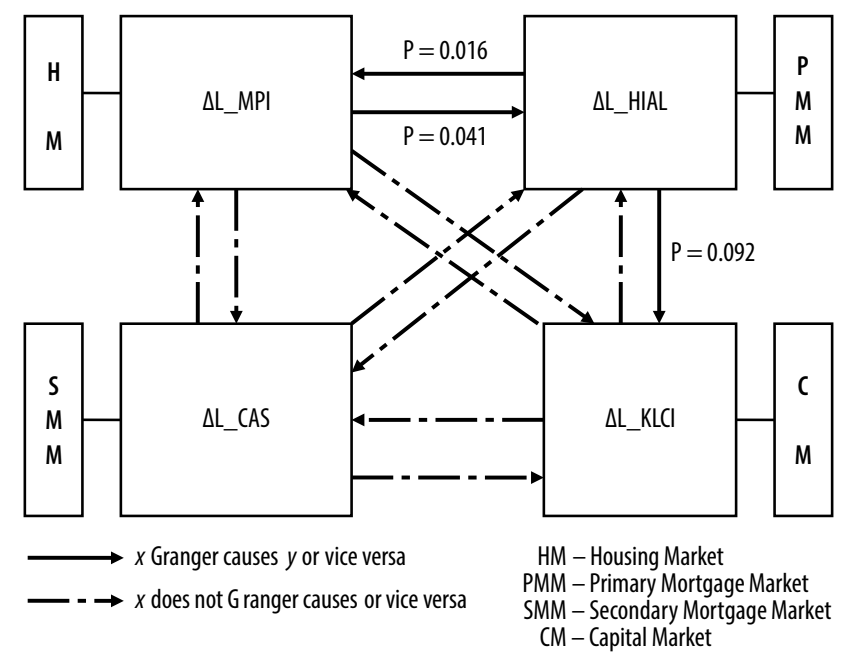

Fig. 3. Causality for lead-lag relationship

indicate that there is a bi-directional causality $(x \leftrightarrow y)$ between changes in the primary mortgage market and changes in the housing market. The test is statistically significance at $5 \%$ critical value. However, the tests were not statistically significant for the causal relationship between the housing market and the secondary mortgage market, and the housing market and the capital market. In other words, no causality was detected between the housing market and these two sub-markets.

The causal relationship between the sub-markets within the housing finance system shows a unidirectional causality $(x \rightarrow y)$ between the primary mortgage market and the capital market. The results show that the primary mortgage market Granger-cause the capital market at $10 \%$ critical regions but the capital market does not Grangercause the primary mortgage market.

\section{SUMMARY AND CONCLUSIONS}

A key finding steering from this analysis is that changes in house prices and housing demand are determined by the housing finance system. Changes in the present house price were significantly affected by the previous change in house price, the primary mortgage market and the capital market. The lead-lag relationship shows that the highest explanatory power of changes in the present house price was the previous changes in the house price itself lagged by two years, the primary and secondary mortgage markets lagged a year and the capital market lagged by four years. Within the housing finance system, changes in the present house price were determined by the present changes in the primary mortgage market and the 
secondary mortgage market and the capital market lagged by four years. Hence, the findings suggest that changes in the present house price were determined by current and previous changes in the housing finance system.

The short-run and long-run inter-relationships were also established to find the implication of lead-lag relationships between the housing market and housing finance system. The finding shows that the secondary mortgage and capital markets provide the highest explanatory power immediately after the occurrence of the shock over the variation of house price changes. However, house price takes up to five years to reach a steady-state level from the first occurrence of the shock to the primary mortgage market. The effect of shocks indicates that the capital market and the house price itself account the highest variation in house price changes. As a result, the combination of previous changes in the housing market and housing finance system are equally responsible to correct the present house price disequilibrium. In addition, the finding from Granger-causality test shows that there was a bi-directional relationship between the housing market and the housing finance system. More specifically, the primary mortgage market shows a bi-directional relationship with the housing market but not for the secondary mortgage and capital markets. Within the housing finance system, there was a unidirectional relationship of which the primary mortgage market was found to Granger-cause the capital market. Therefore, the overall findings suggest that changes in the housing market lead to changes in the housing finance system and vice versa.

The outcomes of the study have contributed in an original way to the knowledge of the Malaysian housing market and housing finance literature where the government housing and monetary policies played important roles. The direction of causality has shown the importance of practising balanced government's interventions in the housing market and housing finance system. Therefore, the implementation of government's policies on housing market should take into consideration the likely effect on the housing finance system and vice versa. Since the study identified the inter-relationship between the housing market and housing finance system, the research could be expanded in future to identify whether the housing market is inter-related with other real estate sub-markets. Each of the real estate sub-markets may react differently to the occurrence of shocks in the market structure but the theme of analysis may be the same due to the nature of real estate as an alternative long term investment compared to the stock market. Interested parties can establish whether there is an inter-relationship between the housing market and the commercial or industrial markets. The idea is to show that during economic boom, the demand for commercial and industrial spaces will be higher and therefore, investment in these two markets may generate new economic activities and employment opportunities resulting in the demand for housing units in that region.

\section{REFERENCES}

Adair, A.; Berry, J.; McGreal, S. 1998. Assessing influences upon the housing market in Northern Ireland, Journal of Property Research 15(2): 121-134. http://dx.doi.org/10.1080/095999198368437

Adair, A. S.; McGreal, W. S.; Young, J. 2001. The changing housing market, in Paris $C$, housing in Northern Ireland - and comparison with the Republic of Ireland. Chartered Institute of Housing, 63-76.

Agus, M. R. 1997. Historical perspective on housing development, in Housing the nation: a definitive study. Cagamas Bhd, Kuala Lumpur, 29-70.

Apergis, N. 2003. Housing prices and macroeconomic factors: prospects within the European Monetary Union, International Real Estate Review 6(1): 63-74.

Asian Development Bank. 2013. Fighting poverty in Asia and the Pacific. Available at: http://www.adb.org/ [accessed 1 March 2013].

Barkham, R. J.; Geltner, D. M. 1996. Price discovery and efficiency in the UK housing market, Journal of Housing Economics 5(1): 41-63. http://dx.doi.org/10.1006/jhec.1996.0003

BNM. 1991. Annual Report. Central Bank of Malaysia, Kuala Lumpur, Malaysia.

BNM. 2007. Annual Report. Central Bank of Malaysia, Kuala Lumpur, Malaysia.

BNM. 2008. Monthly statistical bulletin (various months). Central Bank of Malaysia, Kuala Lumpur, Malaysia.

Brooks, C. 2008. Introductory econometrics for finance. $2^{\text {nd }}$ ed. Cambridge University Press, UK.

Case, K. E.; Shiller, R. J. 2003. Is there a bubble in the housing market?, Brookings Papers on Economic Activity (2): 299-362.

Collyns, C.; Senhadji, A. 2002. Lending booms, real estate bubbles and the Asian crisis, IMF Working Paper No WP/02/20. Washington: International Monetary Fund.

Dickey, D. A.; Fuller, W. A. 1979. Distribution of the estimators for autoregressive time series with a unit root, Journal of the American Statistical Association 74(366): 427-431.

Dickey, D. A.; Fuller, W. A. 1981. Likelihood ratio statistics for autoregressive time series with a unit root, Econometrica 49(4): 1057-1072. 
DiPasquale, D.; Wheaton, W. C. 1994. Housing market dynamics and the future of housing prices, Journal of Urban Economics 35(1): 1-27. http://dx.doi.org/10.1006/juec.1994.1001

Evans, A. W. 1995. The property market: ninety per cent efficient?, Urban Studies 32(1): 5-29. http://dx.doi.org/10.1080/00420989550013194

Garnet, D.; Reid, B.; Riley, H. 1991. Housing finance. Essex: The Institute of Housing (Services) Ltd.

Granger, C. W. J. 1969. Investigating causal relations by econometric models and cross-spectral methods, Econometrica 37(3): 424-438.

Gupta, R.; Jurgilas, M.; Kabundi, A.; Miller, S. M. 2012. Monetary policy and housing sector dynamics in a large-scale Bayesian vector autoregressive model, International Journal of Strategic Property Management 16(1): 1-20. http://dx.doi.org/10.3846/1648715X.2011.621466

Hepsen, A.; Vatansever, M. 2012. Relationship between residential property price index and macroeconomic indicators in Dubai housing market, International Journal of Strategic Property Management 16(1): 7184. http://dx.doi.org/10.3846/1648715X.2011.602756

Herring, R. J.; Wachter, S. 1999. Real estate booms and banking busts: an international perspective, Working Paper 99-27. Wharton Financial Institutions Center, The Wharton School, University of Pennsylvania.

Hilbers, P.; Lei, Q.; Zacho, L. 2001. Real estate market developments and financial sector soundness, IMF Working Paper No. 01/129. Washington: International Monetary Fund.

Holstein, A. D.; O'Roark, B.; Lu, M. 2013. Determinants of the home price-income relationship: 1990-2011, Global Journal of Business Research 7(3): 15-30.

Iacoviello, M.; Minetti, R. 2000. The credit channel of monetary policy and housing markets: international empirical evidence, Bank of Finland Discussion Paper, 14/2000.

Koop, G. 2008. Analysis of economic data. $3^{\text {rd }}$ ed. Chichester: John Wiley \& Sons.
Lea, J. M. 1994. Efficiency and stability of housing finance systems: a comparison of the United Kingdom and the United States, Housing Policy Debate 5(3): 361-379.

Maclennan, D.; Muellbauer, J.; Stephens, M. 1998. Asymmetries in housing and financial market institutions and EMU, Oxford Review of Economic Policy 14(3): 54-80. http://dx.doi.org/10.1093/oxrep/14.3.54

Muellbauer, J.; Murphy, A. 1997. Boom and busts in the UK housing market, Economic Journal 107: 1701-1727. http://dx.doi.org/10.1111/j.1468-0297.1997.tb00076.x

Nadler, M. 2005. Evaluation of housing finance systems. United Nations Economic Commission for Europe (UN-ECE).

Pain, N.; Westaway, P. 1997. Modelling structural change in the UK housing market: a comparison of alternative house price models, Economic Modelling 14(4): 587-610. http://dx.doi.org/10.1016/S0264-9993(97)00007-2

Philips, P. C. B. 1986. Understanding spurious regressions in econometrics, Journal of Econometrics 33(3): 311-340. http://dx.doi.org/10.1016/0304-4076(86)90001-1

Sims, C. A. 1980. Macroeconomics and reality, Econometrica 48(1): 1-48.

Stephens, M. 2003. Globalisation and housing finance systems in advanced and transition economies, $U r$ ban Studies 40(5-6): 1011-1026.

http://dx.doi.org/10.1080/0042098032000074290

Stevenson, S. 2000. A long-term analysis of regional housing markets and inflation, Journal of Housing Economics 9: 24-39. http://dx.doi.org/10.1006/jhec.2000.0258

Tse, R. Y. C. 2004. Hong Kong housing and the Asian financial crisis, Journal of Real Estate Literature 12(1): 21-32.

Warnock, V. C.; Warnock, F. E. 2008. Markets and housing finance, Journal of Housing Economics 17(3): 239-251. http://dx.doi.org/10.1016/j.jhe.2008.03.001 